\title{
Effect of Pre-germination Treatments on the Emergence Percentage of Bitter Gourd cv. CO 1 seeds
}

D. Thirusenduraselvi and *R. Jerlin

Seed Centre, Tamil Nadu Agricultural University, Coimbatore-641 003, Tamil Nadu, India

Accepted 25 $5^{\text {th }}$ August 2007

\begin{abstract}
Poor seedling establishment is a problem with bitter gourd as the embryo is enclosed by a thick seed coat, which affect the germination by imposing mechanical restriction on embryo growth. To overcome this problem, pre germinated seeds of bitter gourd may be sown. Hence, studies were conducted to find out a suitable pre-germination method that could give the maximum percentage of emergence of bitter gourd cv. CO 1 seeds after sowing. For this, the seeds were soaked in water, $\mathrm{CaCl}_{2} @ 2 \%, \mathrm{KNO}_{3} @ 2 \%$, moringa (Moringa oleifera) leaf extract @ 2\% and panchakavya @ 3\% (an organic solution-method of preparation given in the text) for different soaking period viz., 3, 6,9 and $12 \mathrm{~h}$ followed by different durations of incubation viz., 3, 4, 5 and 7 days. Among the different treatments, 100 per cent pre-germination of bitter gourd seeds was achieved when soaked in panchakavya @ 3\% solution for $9 \mathrm{~h}$ with 7 days of incubation which was at par with soaking in $\mathrm{KNO}_{3} @ 2 \%$ solution for $9 \mathrm{~h}$ and incubated for 7 days which recorded 88 per cent germination.
\end{abstract}

Keywords : Pre-germination, panchakavya, pre-germination percentage, bitter gourd

Bitter gourd or balsam pear (Momordica charantia $\mathrm{L}$.) is one of the most popular cucurbitaceous vegetables which find its prime place among the high valuable vegetables, because of its nutritive value and medicinal properties. Field emergence is always a problem in bitter gourd even with the seeds of high germinability due to thick seed coat. To overcome this problem, sowing of pre-germinated seeds which are selected on the basis of an emerged radicle can be practised. Pre-germination resu lts in rapid and uniform seed germination by avoiding uncontrollable effects of the environment on germination and by advancing seed ling emergence. The pre-germinated seed has a limited shelf life and should be planted as soon as possible for obtaining optimum seedling establishment. Pre-germinated seeds proved superior in emergence from the soil and in stand establishment. The additional advantages of this treatment include, (i) lower seed rate, (ii) no need for third day watering after sowing (Life irrigation), (iii) dead seeds can be discarded before sowing, and (iv) germinating, but low vigour seeds can be removed before sowing. Hence, standardization of pre germination treatments was carried out to increase the rate of germination of bitter gourd seeds.

\footnotetext{
*Corresponding author
}

Freshly harvested, genetically pure and cleaned bitter gourd seeds cv. CO 1 were obtained and were size graded and used for the pre-germination treatments. The seeds were subjected to the following pre-germination treatments (Table 1).

$5 \mathrm{~kg}$ of cow dung was mixed with 5 liters of cow urine and $1 / 2 \mathrm{~kg}$ of ghee. The solution was stirred and kept it in a 20-liter mud-pot upto 15 days. On the $16^{\text {th }}$ day $2 \mathrm{~L}$ of curd, $2 \mathrm{~L}$ of milk, $1 \mathrm{~kg}$ of jaggery and $1 / 2 \mathrm{~kg}$ of ripen banana were added and stirred daily for another 7 days. On the $21^{\text {st }}$ day, the panchakavya was ready to use.

Seeds were soaked in double the quantity of the above solutions (100 g seed in $200 \mathrm{ml}$ solu-

\section{Table 1: Pre-germination treatments}

\begin{tabular}{lcc}
\hline Treatment & $\begin{array}{c}\text { Soaking duration } \\
\text { (S) } \\
\text { (h) }\end{array}$ & $\begin{array}{c}\text { Incubation } \\
\text { period (I) } \\
\text { (days) }\end{array}$ \\
\hline $\mathrm{T}_{0}-$ Water soaking & 3 & 3 \\
$\mathrm{~T}_{1}-\mathrm{CaCl}_{2} 2 \%$ & 6 & 4 \\
$\mathrm{~T}_{2}-\mathrm{KNO}_{3} 2 \%$ & 9 & 5 \\
$\mathrm{~T}_{3}-$ Moringa (Mori & 12 & 7 \\
$n g a$ oleifera) leaf ex- & & \\
tract 2\% & & \\
$\mathrm{T}_{4}-$ Panchakavya 3\% & & \\
\hline
\end{tabular}


Table 2: Effect of different pre-germination treatments on the percentage of germinating bitter gourd cv. CO 1 seeds

\begin{tabular}{|c|c|c|c|c|c|c|c|}
\hline \multirow{2}{*}{ Treatments } & \multirow{2}{*}{$\begin{array}{l}\text { Incubation } \\
\text { period (days) }\end{array}$} & \multicolumn{4}{|c|}{ Soaking duration $(\mathrm{h})-(\mathrm{S})$} & \multirow{2}{*}{$\begin{array}{l}\mathrm{T} \times \mathrm{I} \\
\text { Mean }\end{array}$} & \multirow{2}{*}{ T Mean } \\
\hline & & 3 & 6 & 9 & 12 & & \\
\hline \multirow[t]{4}{*}{$\overline{\text { Water }\left(\mathrm{T}_{1}\right)}$} & 3 & 1 & 1 & 2 & 1 & 1 & 46 \\
\hline & 4 & 23 & 26 & 28 & 22 & 25 & \\
\hline & 5 & 67 & 70 & 84 & 51 & 68 & \\
\hline & 7 & 89 & 91 & 93 & 88 & 90 & \\
\hline Tx S Mean & & 45 & 47 & 52.0 & 40.5 & & \\
\hline \multirow{4}{*}{$2 \% \mathrm{CaCl}_{2}\left(\mathrm{~T}_{2}\right)$} & 3 & 2 & 2 & 4 & 2 & 3 & 49 \\
\hline & 4 & 18 & 26 & 42 & 12 & 25 & \\
\hline & 5 & 70 & 77 & 87 & 69 & 76 & \\
\hline & 7 & 91 & 93 & 95 & 89 & 92 & \\
\hline Tx S Mean & & 45 & 49.5 & 57 & 43 & & \\
\hline \multirow[t]{4}{*}{$2 \% \mathrm{KNO}_{3}\left(\mathrm{~T}_{3}\right)$} & 3 & 6 & 7 & 8 & 2 & 6 & 67 \\
\hline & 4 & 72 & 80 & 88 & 59 & 75 & \\
\hline & 5 & 88 & 89 & 90 & 88 & 89 & \\
\hline & 7 & 97 & 98 & 99 & 96 & 96 & \\
\hline Tx S Mean & & 66.0 & 69.0 & 71 & 61 & & \\
\hline \multirow[t]{4}{*}{$2 \%$ Moringa leaf extract $\left(\mathrm{T}_{4}\right)$} & 3 & 3 & 5 & 5 & 2 & 4 & 57 \\
\hline & 4 & 34 & 47 & 69 & 34 & 46 & \\
\hline & 5 & 84 & 85 & 87 & 80 & 84 & \\
\hline & 7 & 93 & 96 & 97 & 91 & 94 & \\
\hline Tx S Mean & & 54 & 58 & 65 & 52 & & \\
\hline \multirow{4}{*}{$3 \%$ Panchakavya $\left(\mathrm{T}_{5}\right)$} & 3 & 27 & 27 & 53 & 18 & 31 & 77 \\
\hline & 4 & 83 & 86 & 88 & 81 & 85 & \\
\hline & 5 & 92 & 95 & 98 & 90 & 94 & \\
\hline & 7 & 98 & 99 & 100 & 98 & 99 & \\
\hline Tx S Mean & & 75 & 77 & 85 & 72 & & \\
\hline \multirow[t]{4}{*}{ S x I Mean } & 3 & 8 & 8 & 14 & 5 & 9 & \\
\hline & 4 & 46 & 53 & 63 & 42 & 41 & \\
\hline & 5 & 80 & 83 & 89 & 76 & 82 & \\
\hline & 7 & 97 & 95 & 97 & 92 & 95 & \\
\hline \multirow[t]{2}{*}{ S Mean } & & 47 & 60 & 66 & 43 & & \\
\hline & I & $\mathrm{S}$ & $\mathrm{T}$ & I x S & $\mathrm{S} \times \mathrm{T}$ & I x T & $\mathrm{I} \times \mathrm{S} \times \mathrm{T}$ \\
\hline SE & 0.39 & 0.39 & 0.44 & 0.78 & 0.88 & 0.88 & 1.75 \\
\hline $\mathrm{CD}(\mathrm{P}=0.05)$ & 0.77 & 0.78 & 0.87 & 1.55 & 1.74 & 1.74 & 3.48 \\
\hline
\end{tabular}

tion). After the specified period of soaking, the solutions were drained off. The seeds were then incubated for different durations viz., 3, 4, 5 and 7 days under ambient conditions in a room (temperature $25-31^{\circ} \mathrm{C}$ ) by spreading a double layer of moist cloth over the heap of soaked seeds. The percentage of germination as judged by radicle emergence was recorded on the respective days after incubation and expressed as percentage. The observed data were statistically analysed by applying Factorial Completely Randomised Block Design (Panse and Sukhatme, 1985).

The embryo of bitter gourd is enclosed by a thick seed coat, which may affect the germination by imposing mechanical restriction on embryo growth (Edelstein et al., 1995). Seed germination can be improved by pre-sowing hydration methods to achieve maximum emer- gence to overcome the problem of thick seed coat. Pre-germination technique involves seed hydration up to the point of radicle protrusion

Pre-germination study was carried out in bitter gourd in order to find out the suitability of using water, chemicals viz., $\mathrm{CaCl}_{2}(2 \%)$, and $\mathrm{KNO}_{3}(2 \%)$, organics viz., moringa (Moringa oleifera) leaf extract (2\%) and panchakavya $(3 \%)$ as the pre-germination treatment. The seeds were soaked in these solutions for $3,6,9$ and $12 \mathrm{~h}$ followed by 3, 4, 5 and 7 days of incubation. The results of the study revealed that seeds soaked in panchakavya $(3 \%)$ for $9 \mathrm{~h}$ followed by 7 days of incubation was superior in recording the maximum percentage of pregermination $(100 \%)$. The germination of the seedlings were advanced in the pre-germinated seeds when compared to the control seeds without pre-germination. 
The crop management today has become more independent of chemical treatment as their hazardous ramification have been recognised. Hence, the agricultural scientists are concentrating an alternate method of using organics to avoid the usage of chemicals. Indian agri-products are known to be more organic than that of most developed countries, keeping in view the traditional agronomic practices foll owed by small farmers (Shazia Shabriar, 2001) and panchakavya has been such piece of traditional wisdom, meant to safeguard plants and soil microorganisms (Natarajan, 2002). The scientific studies available on Panchakavya is very limited to prove their suitability as organic nutrition for the production of field crops.

In the present experiment, the overall mean for soaking the seeds in Panchagkavya (3\%) is 77\%. The improvement due to this treatment was 7.0 per cent over water soaking. The major constituents of panchakavya includes the five constituents of cow viz., cowdung, urine, milk, curd and ghee. The estimation of its constituents showed the presence of macro (N, P and $\mathrm{K})$ and micro $(\mathrm{Zn}, \mathrm{Cu}, \mathrm{Fe}, \mathrm{Mn}$ and $\mathrm{Ca}$ ) nutrients besides total reducing (glucose) sugars, the growth regulators, viz., IAA and GA and naturally occurring, beneficial effective macro organisms (EMO's) predominantly lactic acid bacteria (Lactobacillus), yeast (Saccharomyce $s$ ), actinomycetes (Streptomyces), photosynthetic bacteria and certain fungi apart from beneficial and proven bio-fertilizers such as Acetobacter, Azospirillum and Phosphobacterium (Beaulah, 2001).

All these nutrients, growth regulators and bioactive substances might have accelerated the germination process while the biodigestable enzymes could have been the cause for softening of the thick seed coat of bitter gourd seeds and thereby effecting the radicle protrusion.

The next best pre-germination treatment was $\mathrm{KNO}_{3}(2 \%)$ soaked for $9 \mathrm{~h}$ and incubated for 7 days which recorded 88 per cent germination. It was also plausible that enhanced germination due to potassium nitrate was the outcome of quantitative and qualitative shifts in the protein synthesis induced by the treatment (Leadem, 1987). Moreover potassium nitrate had been reported to raise the ambient oxygen level by making less oxygen available for the citric acid cycle (Bewley and Black, 1982).
The beneficial effects of $\mathrm{KNO}_{3}$ was also supported by Renuga Devi and Jacqueline (1995) in bitter gourd. The effect of pre-sowing soaking treatment on the enhancement of germination and seedling vigour with nitrates have been amply demonstrated in various legumes (Santhakumari and Vivekanandan, 1984 and Kalavathi, 1985). From the present study, it can be inferred that among the five pregermination treatments investigated, 100 per cent germination could be obtained by Panchakavya 3 per cent for $9 \mathrm{~h}$ soaking with 7 days incubation.

\section{REFERENCES}

Beaulah, A. (2001) Growth and development of Moringa (Moringa oleifera Lam.) cv. PKM 1 under organic and inorganic systems of culture. Ph.D. Thesis, Tamil Nadu Agricultural University, Coimbatore - 3 .

Bewley, J.D. and Black, M. (1982) Physiology and Biochemistry of seed in relation to germination. Vol. 2. Springer verlag, Berlin, Heideberg Newyork pp. 24-26 and 34-43.

Edelstein, M., Corbineau, F., Kigel, J. and Nerson, H. (1995) Seed coat structure and oxygen availability control low-temperat ure germination of melon (Cucumis melo) seeds. Physiologia plantarum, 93: 451-456.

Kalavathi, D. (1985) Studies on seed viability and vigour in soybean (Glycine $\max$ (L.) Merrill). M.Sc.(Ag.) Thesis, Tamil Nadu Agricultural University, Coimbatore-3. Lea dem, C.L. (1987). The role of plant growth regulation in the germination of forest tree seeds. Plant growth regulation, 6: 61-93.

Natarajan, K. (2002) Panchakavya - A manual, Other India Press, Mapusa, Goa, India pp. 33.

Panse, U.G. and Sukhatme, P.V. (1985) In : Statistical Methods for Agricultural Workers.ICAR Publication, New Delhi, p. 327340

.Renuga Devi, J. and Jacqueline, A. (1995) Se ed pelleting and soil types on germination and vigour of seeds in ashgourd and rib ed gourd. Madras agric. J., 82(2): 75-77

Santhakumari, T.R. and Vivekanandan, M. (1984) $53^{\text {rd }}$ Annual meeting of society of Biofo. Chem. India. Abst. No.507, p. 155.

Shazia Shabriar (2001) Organic farming averitable goldmine. Agriculture today. pp. 57-58. 